\title{
Aplikasi Teknik Fusi dengan Metode Pansharpening untuk Analisis Penggunaan Lahan pada Wilayah Bali Selatan
}

\author{
I Kadek Adiana Putra, I Made Dedy Setiawan
}

Masuk: 09012021 / Diterima: 22022021 / Dipublikasi: 30062021

\begin{abstract}
The southern Bali region was the center of tourism, especially in the North Kuta District, Kuta District, and South Kuta District. The rapid development of tourism is also supported by the increase in infrastructure development to land changes. It is necessary to monitor and analyze changes in land use. For land use analysis using fusion imagery with HSV method from a combination of AVNIR-2 and PRISM images in 2008. This study aimed at investigating the accuracy level of fusion images, and it can be carried out for land use analysis in the southern Bali region. This research was conducted in several phases, namely: (1) problem identification, (2) data collection, (3) data identification and analysis, (4) and reporting. The analysis results show that the fused image can produce color images with a resolution of $2.5 \mathrm{~m}$, the same as the PRISM image. The results of the accuracy-test with comparative data from Google Earth show that the use of fused land has high accuracy with an overall accuracy of $84.848 \%$, so it was feasible to use the basis for land use analysis. Comparing land use analysis between fusion images and AVNIR-2 shows that the fusion image can interpret objects in more detail because it has a higher resolution. Besides that, the fusion image can identify a new class, namely roads.
\end{abstract}

Keywords: Fusion Technique; ALOS; Land Use

Abstrak Wilayah Bali selatan merupakan wilayah pusat pariwisata khususnya pada wilayah Kecamatan Kuta Utara, Kecamatan Kuta, dan Kecamatan Kuta Selatan. Pesatnya perkembangan pariwisata didukung juga dengan meningkatnya pembangunan infrastruktur sehingga banyak terjadi alih fungsi lahan. Perlu dilakukan pemantauan dan analisis dari perubahan penggunaan lahan tersebut. Untuk analisis penggunaan lahan menggunakan citra fusi dengan metode HSV dari kombinasi citra AVNIR-2 dan PRISM tahun 2008. Penelitian ini bertujuan untuk mengetahui tingkat akurasi citra fusi dan selanjunya dapat dilakukan untuk analisis penggunaan lahan pada wilayah Bali selatan. Penelitian ini dilakukan dalam beberapa fase yaitu: (1) identifikasi masalah, (2) pengumpulan data, (3) identivikasi dan analisis data, (4) serta pelaporan. Hasil analisis menujukan bahwa citra hasil fusi dapat menghasilkan citra berwarna dengan resolusi $2.5 \mathrm{~m}$ sama dengan citra PRISM. Hasil uji akurasi dengan data pembanding Google Earth menunjukan penggunan lahan hasil fusi memiliki akurasi yang tinggi dengan overall akurasi sebesar $84.848 \%$, sehingga layak digunakan dasar untuk analisis penggunaan lahan. Hasil perbandingan analisis penggunaan lahan antara citra fusi dengan AVNIR-2, ternyata citra fusi mampu menginterpretasi objek lebih detail karena memiliki resolusi lebih tinggi, selain itu pada citra fusi dapat mengidentifikasi kelas baru yaitu jalan.

Kata kunci: Teknik Fusi; ALOS; Penggunaan Lahan

This is an open access article under the CC BY-SA license.

Copyright $\odot 2021$ by Author. Published by Universitas Pendidikan Ganesha.

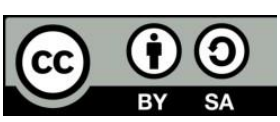

I Kadek Adiana Putra, I Made Dedy Setiawan

STMIK STIKOM, Indonesia

putraadiana@ymail.com

\section{Pendahuluan}

Sistem penginderaan jenis

ALOS memiliki tiga instrumen: di 
antaranya citra Panchromatic Remotesensing Instrument for Stereo Mapping (PRISM) untuk pemetaan elevasi digital, Advanced Visible and Near Infrared Radiometer tipe 2 (AVNIR-2) untuk observasi dan Phased Array type L-band Synthetic Aperture Radar (PALSAR) di perunukan untuk mengmatan malam, ground water atau pengamatan yang tidak memerlukan matahari sebagai sumber tenaga (ALOS, 2007).

Pemanfaatan penginderaan jauh data ALOS (PRISM, AVNIR-2 dan PALSAR) secara umum berorientasi pada ketersediaan data dan kebutuhan jenis informasi yang dimanfaatkan untuk aplikasi pemetaan atau perencanaan pengembangan daerah, serta pengelolaan sumber daya alam (pertanian, peternakan, geologi, perkotaan, dan lain-lain), manajemen bencana, pemantauan lingkungan, dan sebagainya. Untuk memperoleh data secara tepat dan sesuai kebutuhan harus memperhatikan: (1) pemilihan jenis data berkaitan dengan pemilihan kanal/resolusi atau kombinasi spectral dan resolusi spasial. Resolusi temporal dan resolusi radiometrik serta cakupan luas dari unit citra. (2) Prosedur Penentuan atau teknik dan metode pengolahan dan analisis data citra.

Teknik fusi data multisensor penginderaan jauh dapat meningkatkan kualitas informasi yang diperoleh, seperti data optik dan radar, dapat meningkatkan informasi Pada daerah yang mayoritas tutupan awan. Citra pankromatik (hitam dan putih) yang memiliki resolusi spasial tinggi, dan citra multispektral (full colour) dengan resolusi spasial yang rendah, sangat efektif dikobinasikan dengan teknik fusi untuk dapat mempertajam resolusi citra sehingga dapat meingkatkan meningkatkan informasi yang diperoleh (teknik gambar Pan Sharpening), (Aithal dan Kumar, 2009).

Secara umum, teknik fusi citra dapat dibagi menjadi dua kelas: teknik yang terkait warna, dan metode statistik atau numerik. Kelompok pertama terdiri dari komposisi warna dalam merah, hijau, biru ruang warna RGB serta transformasi yang lebih canggih (misalnya IHS). Pendekatan statistik menggunakan saluran statistik termasuk korelasi (Principal Components Analysis (PCA), regresi), dan filter (high pass), sedangkan metode numerik meliputi operasi aritmatika seperti perkalian, pembagian, dan pengurangan (Vrabel, 1996).

Pansharp adalah salah satu metode yang digunakan untuk menggabungkan antara data satelit monokromatik/pankromatik (hitam dan putih) dengan data citra satelit multispektral (berwarna) secara otomatis. Metode penggabungan data otomatis antara data citra satelit pankromatik dan multispektral dikembangkan oleh Dr. Yun Zang dari Jurusan Teknik Geodesi dan Geometrics 'University of New Brunswick, (Abdi, 2011).

Dalam metode pan-sharpening dilakukan dengan mengganti informasi kecerahan watrna asli pada band citra Multi Spektral (MS) resolusi rendah dengan nilai-nilai yang resolusi spasial tinggi dari band pankromatik. Proses ini dilakukan dengan tetap menjaga informasi spektral untuk mempermudah klasifikasi dan analisis citra, (Hanaizumi, 2008). 
Provinsi Bali merupakan salah satu destinasi pariwisata dunia yang menyebabkan tingginya angka in migration atau out migration, nilai ini sangat mempengaruhi indikator demografi yang berimplikasi terhadap tingginya tingkat alihfungsi lahan. Sejalan dengan hal tersebut peningkatan sarana pariwisata terus dikembangkan khususnya pada wilayah Bali Selatan yang menjadi sentral pariwisata di Bali.

2008 merdasarkan data statistik tahun
pariwisata bali passca Bom Bali 1 dan Bom Bali 2, senghingga tingkat hunian dan alih fungsi lahan mengalami peningkatan. Badung merupakan kabupaten di Bali Selatan dengan luas daerah tersebesar yaitu 41.852 ha dan jumlah tujuan wisata tertinggi, dengan rata-rata kepadatan penduduk mencapai 1.293,37 orang/ $/ \mathrm{km}^{2}$ (Badung Dalam Angka, 2008).

Perkembangan pariwisata di wilayah Bali Selatan, khususnya Kecamatan Kuta Utara, Kecamatan Kuta, dan Kecamatan Kuta Selatan mampu menciptakan Bali sebagai destinasi wisata dunia. Sebagai daerah tujuan wisata tentu sarana dan prasarana banyak dibangun, sehingga berpengaruh terhadap meningkatnya alih fungsi lahan pada lahan produktif ataupun lahan non produktif. Dari tahun 1992 sampai tahun 2003 peningkatan lahan terbangun cukup tinggi mencapai 68,69\% (Puspem Badung).

Untuk dapat mengetahui perubahan penggunaan lahan, terlebih dahulu perlu dilakukan analisis penggunaan lahan. Dalam penelitian ini analysis klasifikasi penggunaan lahan dilakukan dari hasil pengolahan citra
ALOS AVNIR-2 dan PRISM denga menggunakan teknik fusi dan metode Phansharpening HSV (Hue, Saturation, Value) untuk dapat menghasilakan citra baru hasil kombinasi dengan resolusi spasial yang lebih tinggi sehingga dapat meningkatkan akurasi dalam melakukan klasifikasi penggunaan lahan.

Metode ini digunakan karna HSV memanfaatkan tiga kanal band pada citra multi spectral yang sesuai dengan warna $R, G$ dan $B$, dengan mentranformasi intensitas $V$ yang merupakan jumlah total cahaya pada citra pada pankromatik, untuk menciptakan sebuah citra baru dengan intensitas sesesuai citra pankromatik.

Adapun tujuan dari penelitian ini adalah untuk mengetahui tingkat akurasi citra AVNIR-2 dengan PRISM hasil fusi dengan menggunakan metode HSV dan mengetahui perbedaan penggunaan lahan pada wilayah bagaian selatan Pulau Bali menggunakan citra fusi dengan citra ALOS AVNIR-2.

\section{Metode}

Penelitian ini berlokasi di wilayah Selatan Pulau Bali khususnya di Kecamatan Kuta Utara, Kecamatan Kuta, dan Kecamatan Kuta Selatan, yang bertujuan untuk menciptakan citra baru dengan resolusi untuk analisis penggunaan lahan.

Metode HSV dilakukan dengan mengubah gambar dalam ruang warna merah-hijau-biru (RGB) menjadi gambar dalam ruang warna HSV (Hue Saturation Value) dengan: mengganti nilai saluran Velue (V) dengan gambar resolusi spasial tinggi, saluran sampel otomatis Hue $(\mathrm{H})$ dan Saturation $(\mathrm{S})$ 
menjadi ukuran elemen citra resolusi spasial tinggi dengan menggunakan teknik nearest neighbour, bilinear, atau cubic convolution technique. Akhirnya, mengubah kembali citra warna RGB untuk ruang warna. Output gambar RGB akan memiliki elemen ukuran gambar++6 yang sama dengan citra resolusi tinggi (Laben, et al., 2005).

$\mathrm{R}_{\mathrm{IHS}}^{\prime} \quad R+($ Pan $-I) \quad R+\delta_{I H S}$

$\mathrm{G}^{\prime}{ }_{\text {IHS }}=G+($ Pan $-I)=G+\delta_{I H S}$

$\mathrm{B}_{\mathrm{IHS}}^{\prime} \quad B+($ Pan $-I) \quad B+\delta_{I H S}$
Dimana $\ddot{\mathrm{a}}_{\mathrm{IHS}}=$ Pan $-\mathrm{I}$ dan citra fusi $\left[R_{I H S}^{\prime}, G_{I H S}^{\prime}, B_{I H S}^{\prime}\right]^{T}$ diperoleh dari gambar asli dengan mengubah ukuran $[R, G, B]^{T}$ dengn operasi sederhana.

Teknik fusi dari resolusi tinggi dan citra penginderaan jauh multispektral, tujuannya adalah memastikan informasi spektral dan menambahkan informasi detail dari resolusi spasial tinggi, oleh karena itu, fusi bahkan lebih memadai untuk pengembang di ruang HIS, (AlWassai, et al., 2011).

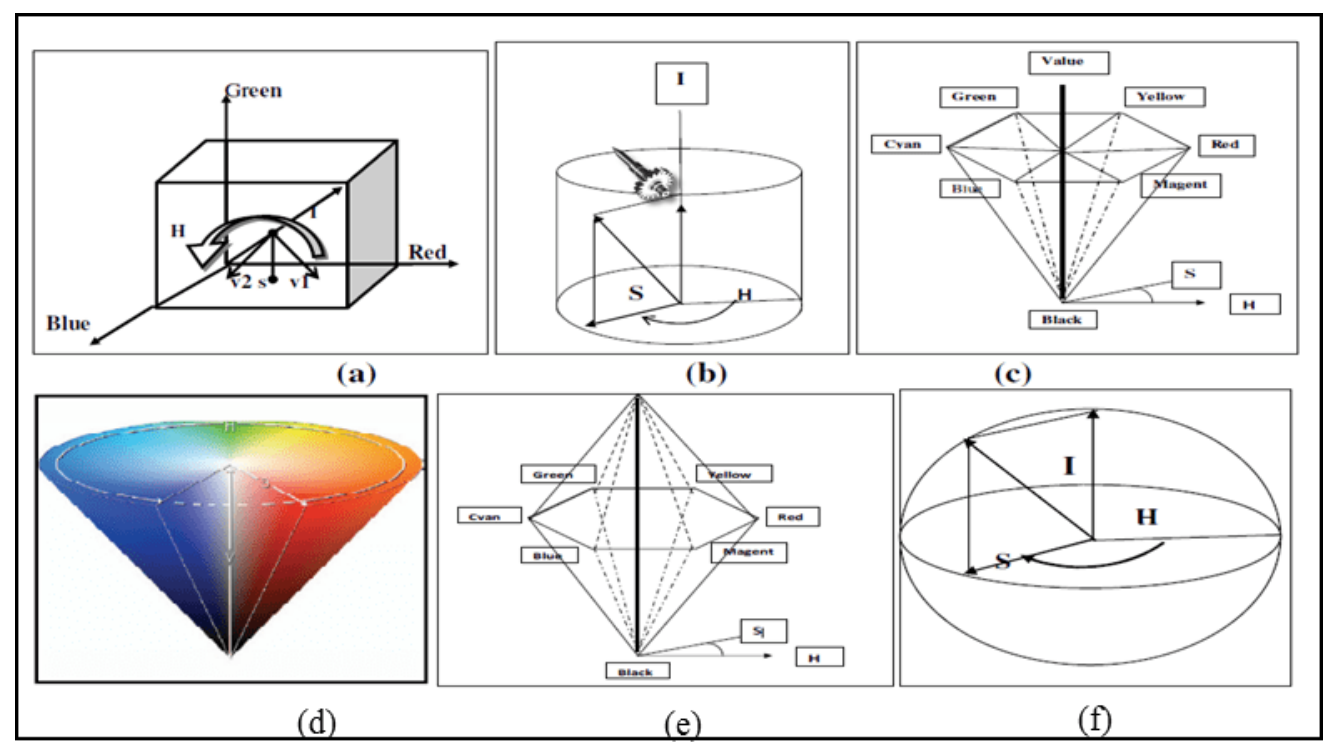

Gambar 1. Model Ruang Warna IHS a) Model Warna Kubus (b) Model Warna Silinder (c) Model Warna Hexcone (d) Warna Bi-Conic Color, (Al-Wassai, et al., 2011).

Desain penelitian ini diawali dari tahap identifikasi data, tahap pengumpulan data, Tahap identifikasi data dan analisis hasil, trahap akhir. Penelitian ini menggunakan metode analisis deskriptif kuantitatif. Deskrip kualitatif adalah untuk jelaskan penggunaan tkenik fusi dengan metode phansarpening HSV untuk menghasilkan citra baru multyspectral dan memliki resolusi tinggi. Untuk lebih jelas alur algoritma umum fusi dapat dilihat pada Gambar 2.

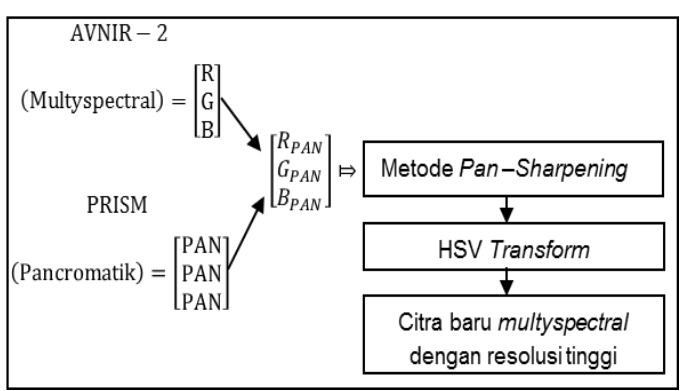

Gambar 2. Algoritma Fusi dengan metode pansharpening HSV 
AVNIR-2 juga memiliki resolusi spasial $10 \mathrm{~m}$, perbaikan dari resolusi spasial $16 \mathrm{~m}$ dari AVNIR yang merupakan citra multi-spektral. Peningkatan detektor CCD (AVNIR memiliki 5.000 pixel per CCD, AVNIR-2 7.000 pixel per CCD) dan mengaktifkan elektronik dengan resolusi lebih tinggi, untuk panjang lintasan ALOS AVNIR-2 dapat dilihat pada Gambar 3. (ALOS, 2007).

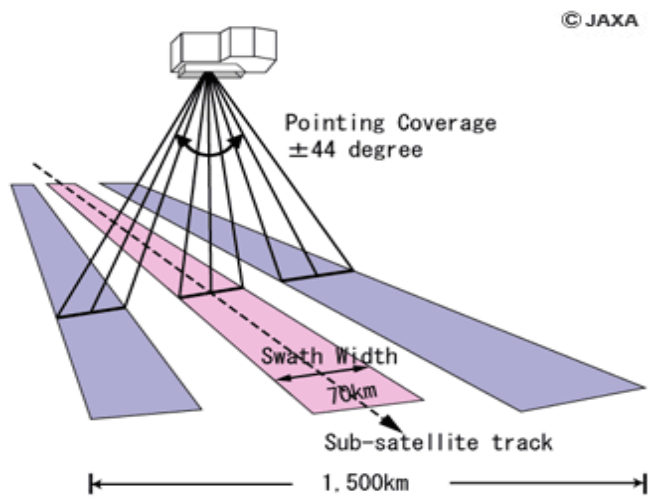

Gambar 3. Panjang Lintasan ALOS

(AVNIR 2), (Schneider. dkk, 2006)

Sumber data yang digunakan dalam penelitian ini adalah citra ALOS AVNIR-2 (multi spectral) dengan reseolusi spasial $10 \mathrm{~m}$ dan ALOS PRISM (pankromatik) resolusi $2,5 \mathrm{~m}$ wilayah bali setalan dengan akusisi waktu tahun 2008. Citra tahun 2008 dipilih karena pengaruh perawanan yg tinggi pada tahun - tahun yang lain.

Citra fusi dilakukan uji akurasi menggunakan Kappa analisis confusion matrixs dengan Google Earth sebagi data pembanding, hasil uji akurasi dilakukan analisis penggunaan lahan dengan klasifikasi superpise dan klasifikasi on screen (klasifikasi visual) sehingga menghasilkan peta penggunaan lahan baru.

Sebuah peta tematik hasil klasifikasi klasifikasi dapat akurat jika memberikan gambaran representasi objektif tentang tutupan lahan di wilayah tersebut. Oleh karena itu, akurasi klasifikasi diartikan sejauh mana klasifikasi citra sesuai dengan realitas ata kebenaran, Campbell, dalam Foody (2002).

Klasifikasi penginderaan jauh dan data referensi, diharapkan nilai KHAT positif. nilai KHAT di kelompokan mejadi tiga: akurasi tinggi dari 0,80 (yaitu,> $80 \%$ ) merupakan perjanjian yang kuat; nilai antara 0,40 - 0,80 (40$80 \%$ ) merupakan nilai akurasi moderat; dan nilai di bawah 0,40 (I, e,. $<40 \%$ ) merupakan nilai akurasi rendah, (Foody, 2002).

\section{Confusion Matrix}

Ground Truth (Persen) Tabel menunjukkan distribusi kelas persen untuk masing-masing kelas kebenaran tanah. Nilai-nilai yang dihitung dengan membagi jumlah pixel di setiap kolom kebenaran tanah dengan jumlah total piksel dalam kelas kebenaran tanah yang diberikan, (Anonim, 2015). Ground truth gigunakan untuk menguji ketelitian dan akurasi hasil klasifikasi kelas penggunaan lahan dari citra hasil fusi dengan kondisi sebenarnya dengan bantuan citra google earth, Contoh tabel Ground truth confusion matrix dapat dilihat pada Tabel. 1. 
Tabel 1. Ground Truth Confusion Matrix

\begin{tabular}{llccccccc}
\hline & Hutan & Tegalan & Sawah & Pemukiman & $\begin{array}{c}\text { Tanah } \\
\text { kosong }\end{array}$ & air & ACC \\
\hline Ground & Hutan & 440 & 40 & 0 & 0 & 30 & 10 & 0.83 \\
Truth & Tegalan & 20 & 220 & 0 & 0 & 40 & 10 & 0.71 \\
& Sawah & 10 & 10 & 210 & 10 & 50 & 10 & 0.58 \\
& Pemukiman & 20 & 0 & 20 & 240 & 100 & 10 & 0.56 \\
& Tanah & 0 & 0 & 10 & 10 & 230 & 0 & 0.88 \\
& kosong & & & & & & & \\
& air & 0 & 20 & 0 & 0 & 0 & 240 & 0.89 \\
& REL & 0.90 & 0.76 & 0.88 & 0.92 & 0.51 & 0.86 & \\
\hline
\end{tabular}

\section{Comisi}

Errors commission mewakili piksel yang dimiliki kelas berbeda dan diberi kode untuk kelas tertentu. Kesalahan komisi ditampilkan di baris confusion matrix, (Anonim, 2015).

\section{Omisi}

Errors omission merupakan piksel yang dimiliki kesalahan analisis dalam jenis penggunaan lahan dalam melakukan analisis yang lebih akurat. Kesalahan dari kelalaian ditunjukkan dalam kolom confusion matrix, (Anonim, 2015).

Untuk mengetahui tingkat kedetailannya peta hasil fusi dibandingkan dengan peta hasil analisis dari citra ALOS AVNIR-2. Secara detail teknik analisis ini dapat dilihat pada Gambar 4.

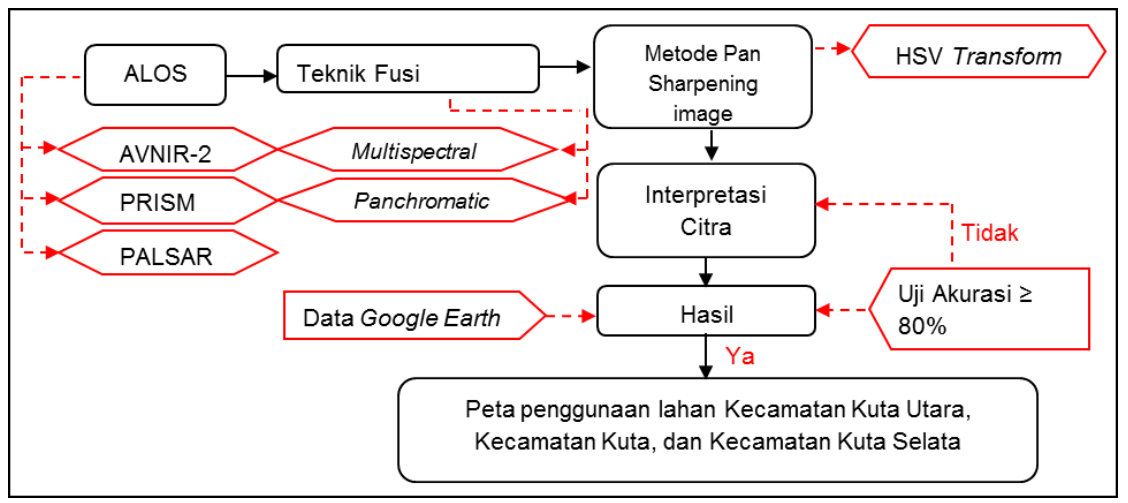

Gambar 4. Detail Teknik Analisis

\section{Hasil dan Pembahasan}

Penggunaan teknik fusi dengan menggunaan metode phansarpening HSV dapat menghasilkan citra berwarna (multyspectral) dengan resolusi tinggi.

\section{Fusi dengan Metode Pahnsarpening HSV}

Dalam penggunaan teknik fusi dengan metode phansarpening HSV, ALOS AVNIR-2 dengan PRISM menghasilkan citra baru dengan 
resolusi tinggi $2,5 \mathrm{~m}$ sesuai dengan resolusi pada PRISM.

Teknik fusi dengan metode pansharpening HSV dapat menghasilkan citra baru berwarna dengan resolusi tinggi. Dalam fusi juga dilakukan komposit dengan kombinasi 3,2,1 untuk warna asli dan 4,3,2 untuk kenampakan vegetasi. Citra komposit hasil fusi memliki ketajaman yang tinggi sesuai dengan resolusi citra PRISM. Pada ALOS AVNIR-2 terdapat gangguan sehingga mempengaruhi analisis objek. Citra fusi dapat menghilangkan gangguan awan, sehingga dapat lebih mudah dalam melakukan analisis dan interpretasi, kecuali pada objek yang sama pada kedua citra tertutp awan tebal teknik fusi tidak dapat menghilangkannya.

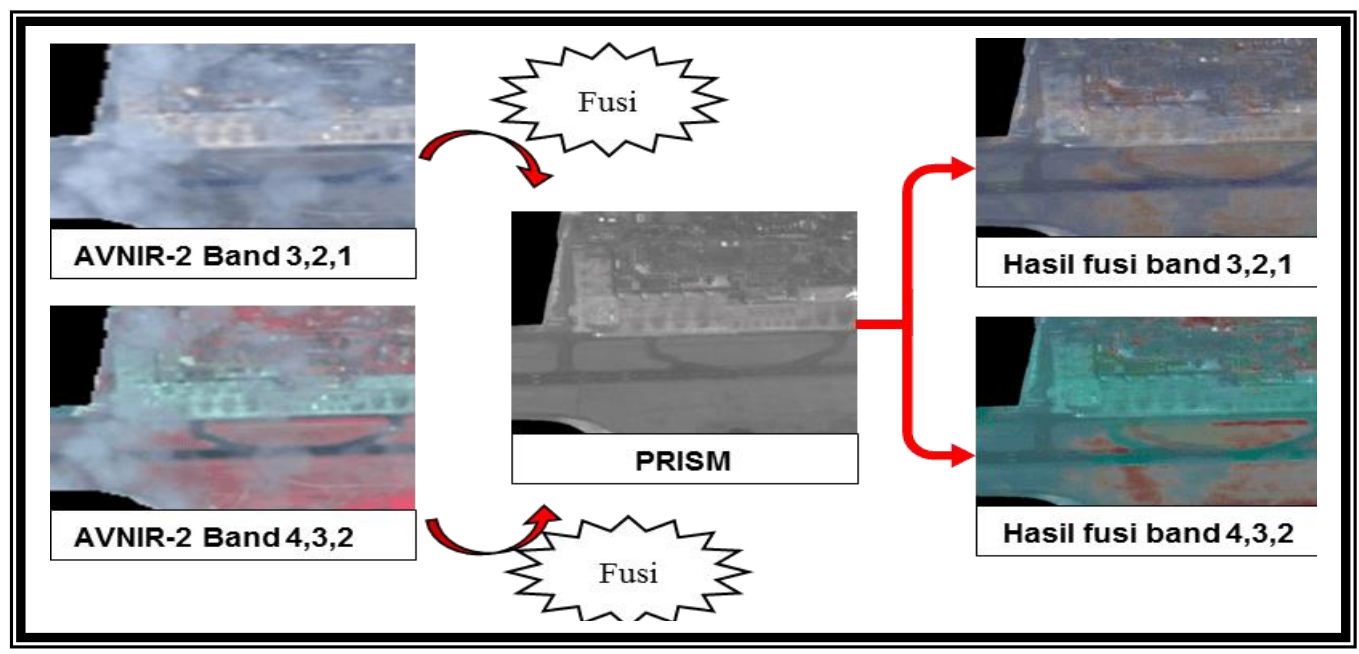

Gambar 5. Citra Fusi Dengan Metode Pansharpening HSV

\section{Hasil Uji Akurasi Citra Fusi}

Dalam uji akurasi, digunakan Google Earth sebagai data pembanding. Data Google earth dipilih karena memiliki resolusi temporal yang tinggi, resolusi spasial yang tinggi, menampilakan informasi secara geometrik, dan dapat menampilkan citra yang bersih tanpa awan. Citra google earth yang dipilih sebagai meda uji akurasi adalah citra yang memiliki akusisi waktu yang sama dengan citra AVNIR-2 dan PRISM yaitu tahun 2008. Tahun yang sama dipilih untuk menyamakan hasil perekaman data. Untuk sebaran titik dapat dilihat pada Gambar 6.

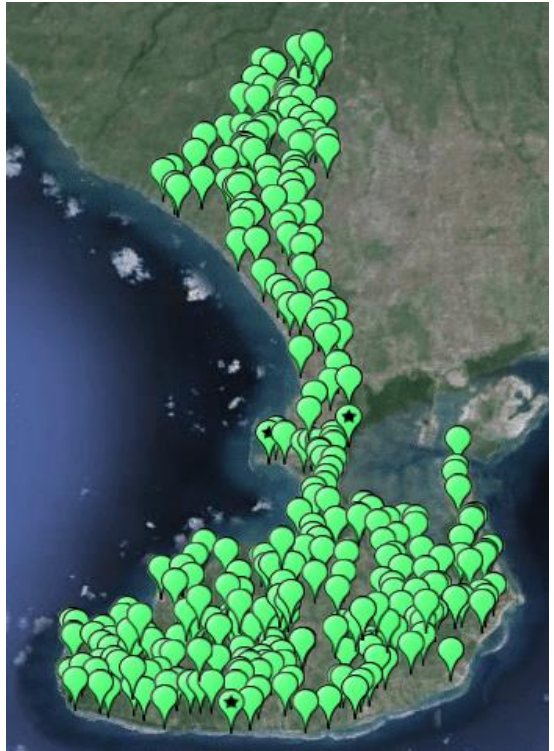

Gambar 6. Sebaran Titik Sampel Citra Fusi 
Dalam analisis akurasi jumlah sampel dipilih $10 \%$ dari total seluruh piksel citra fusi yaitu sebanyak 297 piksel yang dipilih secara acak.
Legenda kalsifikasi jenis lahan dan error matrix dapat dilahat pada Tabel 2 dan Tabel 3.

Tabel 2. Legenda Klasifikasi Jenis Lahan

\begin{tabular}{cl}
\hline Kode & \multicolumn{1}{c}{$\begin{array}{c}\text { Kelas Penggunaan } \\
\text { Lahan }\end{array}$} \\
\hline 1 & Lahan Kosong \\
2 & Bangunan \\
3 & Semak \\
4 & Awan \\
5 & Rumput \\
6 & Sawah \\
7 & Mangrove \\
8 & Tegalan \\
9 & Kebun \\
10 & Jalan \\
11 & Pasir Pantai \\
12 & Pemukiman \\
13 & Air \\
\hline
\end{tabular}

Tabel 3. Error Matrix: Data Refrensi Dalam Kolom, Data Klasifikasi Dalam Baris

\begin{tabular}{ccccccccccccccc}
\hline Kode & $\mathbf{1}$ & $\mathbf{2}$ & $\mathbf{3}$ & $\mathbf{4}$ & $\mathbf{5}$ & $\mathbf{6}$ & $\mathbf{7}$ & $\mathbf{8}$ & $\mathbf{9}$ & $\mathbf{1 0}$ & $\mathbf{1 1}$ & $\mathbf{1 2}$ & $\mathbf{1 3}$ & SUM \\
\hline 1 & 1 & 0 & 0 & 0 & 0 & 0 & 0 & 0 & 0 & 0 & 0 & 0 & 0 & $\mathbf{1}$ \\
2 & 0 & 2 & 0 & 0 & 0 & 0 & 0 & 0 & 0 & 0 & 0 & 0 & 0 & $\mathbf{2}$ \\
3 & $\mathbf{3}$ & $\mathbf{1}$ & $\mathbf{9 8}$ & $\mathbf{0}$ & $\mathbf{0}$ & $\mathbf{0}$ & $\mathbf{0}$ & $\mathbf{1}$ & $\mathbf{4}$ & $\mathbf{0}$ & $\mathbf{0}$ & $\mathbf{0}$ & $\mathbf{0}$ & $\mathbf{1 0 8}$ \\
4 & 0 & 0 & 0 & 0 & 0 & 0 & 0 & 0 & 1 & 0 & 0 & 0 & 0 & $\mathbf{1}$ \\
5 & 0 & 0 & 0 & 0 & 5 & 0 & 0 & 0 & 0 & 0 & 0 & 0 & 0 & $\mathbf{5}$ \\
6 & 0 & 0 & 0 & 0 & 0 & 32 & 0 & 0 & 0 & 0 & 0 & 3 & 0 & $\mathbf{3 5}$ \\
7 & 0 & 0 & 0 & 0 & 0 & 0 & 3 & 0 & 0 & 0 & 0 & 0 & 0 & $\mathbf{3}$ \\
8 & $\mathbf{0}$ & $\mathbf{0}$ & $\mathbf{0}$ & $\mathbf{0}$ & $\mathbf{0}$ & $\mathbf{0}$ & $\mathbf{1}$ & $\mathbf{1 5}$ & $\mathbf{0}$ & $\mathbf{0}$ & $\mathbf{0}$ & $\mathbf{0}$ & $\mathbf{0}$ & $\mathbf{1 6}$ \\
9 & 0 & 1 & 3 & 0 & 0 & 0 & 0 & 0 & 25 & 0 & 1 & 1 & 0 & $\mathbf{3 1}$ \\
10 & 0 & 0 & 0 & 0 & 0 & 0 & 0 & 0 & 0 & 1 & 0 & 1 & 0 & $\mathbf{2}$ \\
11 & 0 & 0 & 0 & 0 & 0 & 0 & 0 & 0 & 0 & 0 & 0 & 0 & 0 & $\mathbf{0}$ \\
12 & 2 & 0 & 5 & 0 & 0 & 0 & 0 & 0 & 11 & 0 & 0 & 69 & 0 & $\mathbf{9 1}$ \\
13 & 0 & 0 & 1 & 0 & 0 & 0 & 0 & 0 & 0 & 0 & 0 & 0 & 1 & $\mathbf{2}$ \\
SUM & $\mathbf{6}$ & $\mathbf{4}$ & $\mathbf{1 0 7}$ & $\mathbf{0}$ & $\mathbf{5}$ & $\mathbf{3 2}$ & $\mathbf{4}$ & $\mathbf{1 6}$ & $\mathbf{4 1}$ & $\mathbf{1}$ & $\mathbf{1}$ & $\mathbf{7 5}$ & $\mathbf{1}$ & $\mathbf{2 9 7}$ \\
\hline
\end{tabular}

Hasil analisis akurasi menggunakan kappa analisis adalah sebagai berikut :

$\begin{array}{lll}\text { Overall Accuracy } & :(252 / 297)=0.848484848 & =84.848 \% \\ \text { Overall Misclassification Rate } & :(45 / 297)=0.151515152 & =15.151 \% \\ \text { Overall Sensitivity } & : 0.848484848 & =84.848 \% \\ \text { Overall Specificity } & : 0.987373737 & =98.737 \% \\ \text { Overall Omission Error } & : 0.151515152 & =15.151 \% \\ \text { Overall Commission Error } & : 0.012626263 & =1.263 \%\end{array}$


Sesuai hasil analisis akurasi menunjukan terdapat beberapa kelas tidak memiliki nilai sperti, awan dan pasir pantai. Akan tetapi secara umum hasil akurasi citra fusi memiliki akurasi yang tinggi berdasarkan nilai overall akurasi sebesar $84,848 \%$ dan nilai errornya sebesar $15,515 \%$.

\section{Analsis Penggunaan Lahan Dengan Citra Fusi}

Analisis penggunaan lahan menggunakan citra fusi dengan resolusi spasial 2,5m dapat menampilkan kelas penggunaan lahan dengan jelas dan akurat, serta hasil fusi ini juga dapat meminimalisir terjadinya distorsi. Dalam analisis ketajaman kelas penggunaan lahan pada citra fusi dilakukan perbandingan dengan klasifikasi dari citra AVNIR-2 dengan resolusi spasial $10 \mathrm{~m}$ yang tanpa dilakukan teknik fusi. Perbandingan hasil analisis penggunaan lahan dapat dilihat pada Gambar 7.

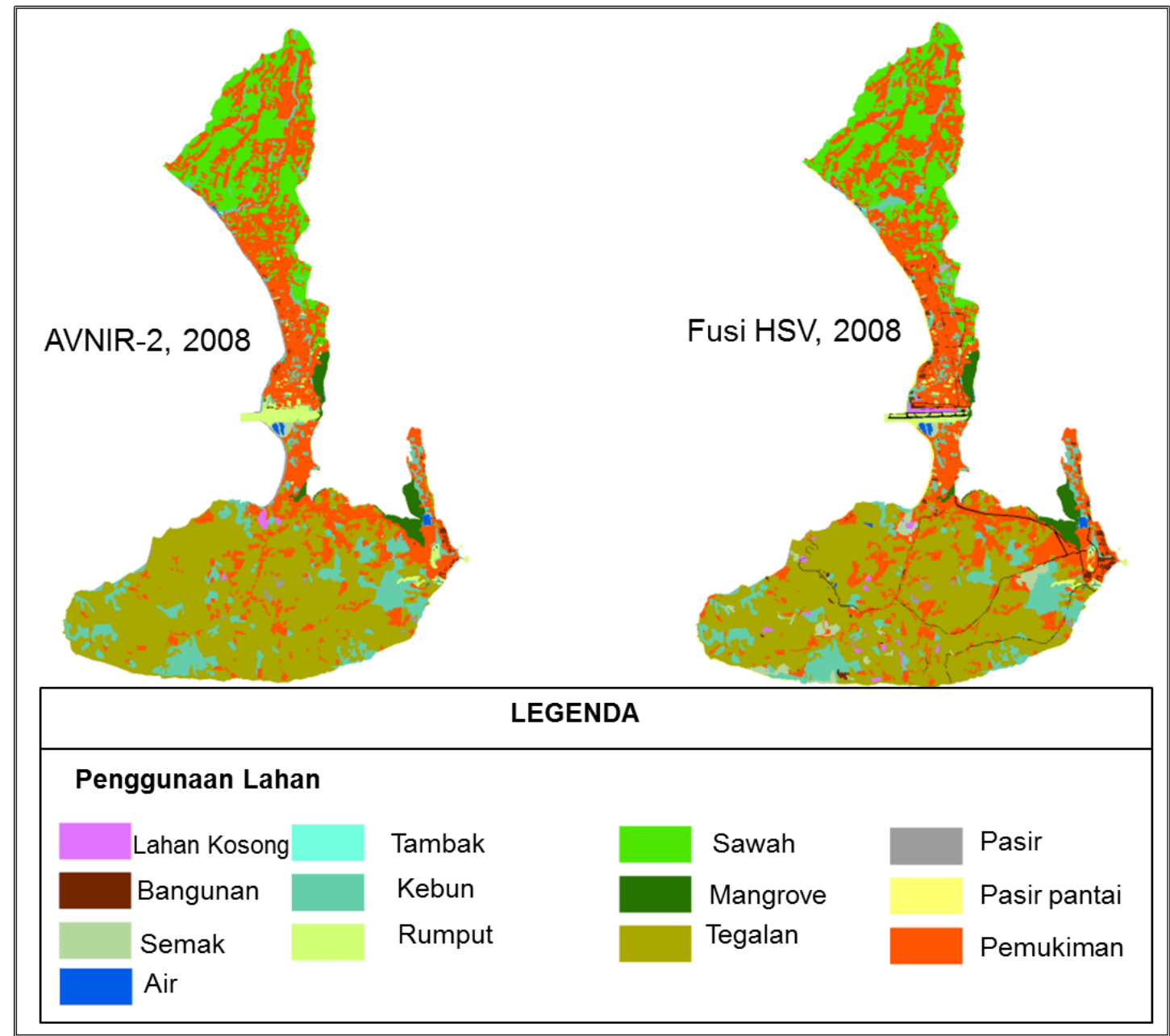

Gambar 7. Hasil Analsis Penggunaan Lahan Citra Fusi Dengan AVNIR-2 di Wilayah Bali Selatan Tahun 2008

Dari analisis visual menunjukan terdapat kelas penggunaan yang berbeda khususnya pada penggunaan lahan pada citra hasil fusi dapat 
menampilkan kelas jalan. Berdasarkan data luas lahan menunjukan adanya variasi penggunaan lahan yang sangat tinggi khususnya pada kelas penggunaan lahan tegalan, pemukiman, sawah dan bangunan. Untuk lebih jelas data perbandingan nilai kelas penggunaan lahan antara citra fusi dengan AVNIR-2 tahun 2008 dapat dilihat pada Tabel 4.

Tabel 4. Perbandingan Nilai Kelas Penggunaan Lahan Citra Fusi Tahun 2008 Dengan Citra AVNIR-2 Tahun 2008.

\begin{tabular}{lll}
\hline $\begin{array}{l}\text { Penggunaan } \\
\text { Lahan }\end{array}$ & 2008 (Km) & $\begin{array}{c}\text { 2008 Fusi } \\
(\mathrm{Km})\end{array}$ \\
\hline Lahan kosong & 36,393 & 64,12431 \\
Bangunan & 62,058 & 187,09604 \\
Semak & 35,101 & 28,96866 \\
Tambak & 3,51 & 3,51 \\
Air & 44,667 & 65,634 \\
Kebun & 1691,637 & 900,4133 \\
Rumput & 307,236 & 134,739 \\
Sawah & 3214,917 & 5172,882 \\
Mangrove & 1234,448 & 1943 \\
Tegalan & 6484,998 & 7369,263 \\
Pasir & 205,587 & 109,065 \\
Pasir Pantai & 1310,096 & 457,217 \\
Pemukiman & 5281,029 & 2195,1497 \\
Awan & & 223,185 \\
Jalan & & 895,635 \\
TOTAL & $\mathbf{1 9 9 1 1 , 6 7 7}$ & $\mathbf{1 9 7 4 9 , 8 8 2}$ \\
\hline
\end{tabular}

Perbedaan resolusi pada kedua citra mempengaruhi tingkat kedetailan analsis, resolusi $10 \mathrm{~m}$ pada AVNIR-2 dengan $2,5 \mathrm{~m}$ pada citra fusi memiliki perbedaan dan penyimpangan nilai yang tinggi khususnya pada kelas penggunaan lahan yang sempit. Untuk lebih jelas, variasi kelas pnggunaan lahan antara AVNIR-2 dengan citra fusi dapat dilihat Gambar 8.

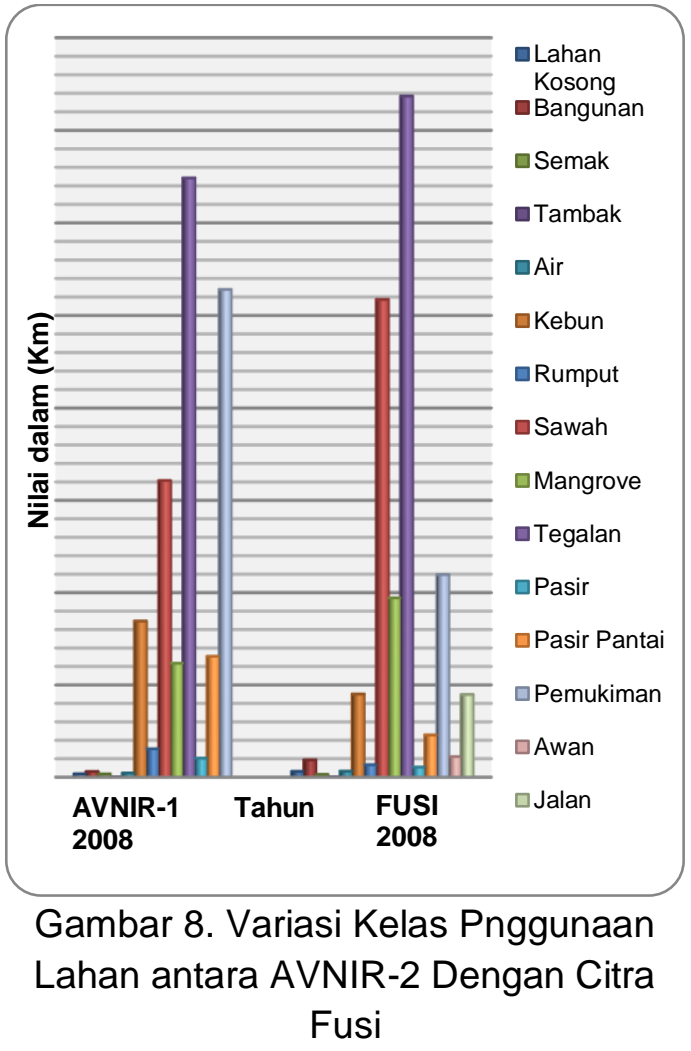

Hasil pengolahan data citra menggunakan teknik fusi dengan metode pansharpening HSV yang menggabungkan antara citra AVNIR-2 tahun 2008 dengan PRISM tahun 2008, dapat menghasilkan citra baru dengan warna yang tajam dan resolusi tinggi yaitu $2,5 \mathrm{~m}$ setelah dilakukan komposit $3,2,1$ dan $4,3,2$.

Selain memliki resolusi tinggi dan warna yang tajam, teknik fusi dengan metode pansharpening HSV juga dapat menghilangkan gangguan awan, sehingga obek yang tidak jelas karena tutupan awan dapat dihilangkan sehingga dapat dengan mudah untuk dilakukan interpretasi objek. Tidak semua awan dapat dihilangkan dalam teknik fusi ini, awan yang terdapat pada AVNIR-2 saja yang dapat dihilangkan yaitu dengan melakukan inferst terhadap citra PRISM, sehingga hasil 
fusi terlihat jernih tanpa awan. Akan tetapi tutupan awan pada citra PRISM tidak dapat dihilangkan sehingga beberapa objek hasil fusi masih terlihat tutupan dari awan pada PRISM.

Dari berbagai metode teknik fusi citra seperti Metode Transformasi Brovey, Metode Principal Component Analysis (PCA), Gram-Schmidt seperti pernelitian yang dilakukan oleh (Putrri. Dkk, 2018) menunjukan metode HSV dapat menghasilkan resolusi sesuai resolusi citra multi spectral sehingga mempermudah dalam melakukan klasifikasi kelas penggunaan lahan, akan tetapi kelemahan dari metode ini adalah nilai DN (digital Number) dirubah kedalah ruang gambar pada satuan RBG sehingga tidak bisa dilakukan koreksi lebih lanjut.

Berdasarkan hasil analisis sampel sebanyak $10 \%$ dari total sampel di komparasi dengan data Google Earth menunjukan bahwa tingkat akurasi citra fusi sebesar $84,848 \%$. Sesuai dengan kappa analisis menunjukan nilai overall accuracy sebesar $84,848 \%$ dan overall omission error sebesar $15,151 \%$. Dengan nilai akurasi $84,848 \%$ telah melampaui standar akurasi yaitu $80 \%$, sehingga citra fusi dapat digunakan sebagai acuan dalam melakukan interpretasi penggunaan lahan. Terdapat penyimpangan dalam analisis akurasi sehingga mempengaruhi nilai akurasi citra yaitu, hasil klasifikasi citra fusi terdapat kelas awan dan pasir pantai sedangkan pada Google Erath pada titik tersebut tidak terdapat kelas awan dan pasir pantai sehingga penyimpangan ini menyebabkan penurunan hasil akurasi. Walaupun demikian dengan nilai $84,848 \%$ merupakan nilai yang tinggi sebagai acuan dalam analisis penggunaan lahan.

Hasil analisis penggunaan lahan pada wilayah Bali selatan khususnya pada Kecamatan Kuta Utara, Kecamatan Kuta, dan Kecamatan Kuta Selatan dengan menggunakan perbandingan kedua citra antara AVNIR-2 dengan Citra fusi, keduanya sama-sama menampilkan kelas penggunaan lahan yang sama. Akan tetapi dengan resolusi spasial yang dimiliki AVNIR-2 yaitu $10 \mathrm{~m}$ berbanding 2,5 m memberikan nilai kedetailan objek yang berbeda. Pada objek dengan luas $<10 \mathrm{~m}$ tidak bisa diidentifikasi pada citra AVNIR-2 karena nilai selnya adalah $10 \mathrm{~m}$ sehingga nilai sel pada objek tersebut akan digabung dengan objek lain disekitarnya dan menjadi satu raster. Sedangkan pada fusi dengan nilai sel $2,5 \mathrm{~m}$ dapat mengidentifikasi objek dengan luas $<10$ $\mathrm{m}$ dan $\geq 2,5 \mathrm{~m}$ sehingga dapat menginterpretasi objek lebih rinci dari pada citra AVNIR-2. Hal tersebut yang menyebabkan nilai beberapa kelas penggunaan lahan yang sama pada kedua citra memiliki variasi yang tinggi khususnya pada kelas sawah, bangunan, pemukiman dan tegalan. Selan kelas tersebut dengan resolusi 2,5 dan warna yang tajam citra fusi juga dapat menampilkan kelas yang berbeda yaitu kelas jalan yang tidak terdapat pada hasil interpretasi pada AVNIR-2.

\section{Penutup}

Aplikasi teknik fusi dengan metode pansharpening HSV (Hue Saturation and Value) dapat menciptakan citra baru berwarna (multispectral) dengan resolusi tinggi, 
selain itu metode pansharpening juga dapat menghilangkan pengaruh awan pada objek. Dengan nilai akurasi tinggi yaitu $84,848 \%$ dapat menjadi acuan dalam interpretasi untuk klasifikasi penggunaan lahan. Perbedaan analisis citra fusi dengan citra AVNIR-2 adalah citra fusi dapat menampilkan kelas yang lebih detail dari citra AVNIR-2. Selain lebih detail citra fusi juga dapat menghasilkan kelas baru yaitu kelas jalan. Dengan menggunakan teknik fusi dapat mempermudah melakukan klasifikasi wilayah perkotaan yang secara umum memerlukan data satelit serolusi tinggi.

\section{DAFTAR PUSTAKA}

Abdi. 2011. Pan-Sharpening. [Cited 2013 Feb. 17] Available from: URL:

http://mtnugraha.wordpress.com /2011/10/31/pan-sharpening.

Aithal, Bharath $\mathrm{H}$. and Kumar, Uttam. 2009. Fusion of Multi Resolution Remote Sensing Data For Urban Sprawl Analysis. COSMAR 09. Indian Institute of Science.

ALOS. 2007. Daichi - Advend Land Observing Satellite. [Cited 2013 Feb. 13]. Available from: URL: http://www.eorc.jaxa.jp/ALOS/en /about/avnir2.htm.

Al-Wassai, Firouz Abdullah., Kalyankar, N.V., Al-Zuky, Ali A. 2011. The IHS Transformations Based Image Fusion (Research Student). Nanded, India. Yeshwant College.

Anonim. 2015. Calculate Confusion Matrices. [Cited 2015, june 17] available from: URL: http://www.exelisvis.com/docs/C
alculatingConfusionMatrices.htm

I.

Badung dalam Angka. 2009. Bappeda Litbang Kabupaten Badung Badan Pusat Statistik Kabupaten Badung (Katalog BPS : 1102001.5103).

Hanaizumi, Akiba, M, Yamano, $\mathrm{H}$, and Matsunaga, T. 2008. A pansharpening method for satellite image-based coral reef monitoring with higher accuracy : Proceedings of the 11th International Coral Reef Symposium, Ft. Lauderdale, Florida, 7-11 July 2008. Session number 17. Japan. Hosei University, Faculty of Computer and Information Sciences, 3-7-2 Kajino-cho, Koganei, Tokyo 184-8584.

Laben, Muthusamy. S., Rosario, Arunkumar. X. 2005. Process for Enhancing the Spatial Resolution of Multispectral Imagery Using Pan-Sharpening, US Patent 6,011,875. [Cited. 2013, February 13] Avilable from: URL

http://www.exelisvis.com/docs/gr amschmidtspectralsharpening.ht $\mathrm{ml}$.

Putri, D. R. 2018. Analisis Kombinasi Citra Sentinel-1A dan Citra Sentinel-2A Untuk Klasifikasi Tutupan Lahan (Studi Kasus: Kabupaten Demak, Jawa Tengah). Jurnal Geodesi Undip. 7(2).

Schneider, Mathias., Lehner, Manfred., Müller, Rupert. And Reinartz, Peter. 2006. Stereo Evaluation of ALOS/PRISM Data On EsaAo Test Sites - First DLR 
Results. German Aerospace

Center (DLR), Remote Sensing

Technology Institute, D-82234

Wessling, Germany.

Vrabel, J. 1996. Multispectral Imagery

Band Sharpening Study.

Photogrammetric Engineering \&

Remote Sensing. 62(9): 1075-

1083.

74 | Media Komunikasi Geografi, Vol. 22, No. 1, Juni 2021: 62-74 